\title{
Calvin and human dignity
}

\author{
J.M. Vorster \\ School for Ecclesiastical Studies \\ Potchefstroom Campus \\ North-West University \\ POTCHEFSTROOM \\ E-mail: koos.vorster@nwu.ac.za
}

\begin{abstract}
Calvin and human dignity

Human dignity has become a major moral directive in the contemporary ethical reflection on human rights and bio-ethics. This article examines the theological foundations laid by the reformer Calvin regarding the inherent dignity of people, and his influence on post-World War ethical reflection about the violations of human rights. In this article his views on the "imago dei" and common grace, the "lex naturae" and the obligations of the civil authority are investigated in order to illuminate his ideas about the dignity of human beings. The article then deals with the influence of these ideas in the influential works of the twentieth century's reformed theologians Barth, Berkhouwer and Moltmann.
\end{abstract}

\section{Opsomming}

\section{Calvyn en menswaardigheid}

Menswaardigheid het 'n vername morele riglyn geword in die kontemporêre etiese refleksie op menseregte en bioetiek. Hierdie artikel ondersoek die teologiese grondslae wat deur die hervormer, Calvyn, gelê is in verband met die inherente menswaardigheid van mense, asook sy invloed op die na-wêreldoorlogse etiese refleksie oor die skending van menseregte. In hierdie artikel word sy standpunte oor die "imago dei" en algemene genade, die "lex naturae" en die verpligtings van die burgerlike owerheid ondersoek, om daardeur sy idees oor menseregte uit te lig. Die artikel handel vervolgens ook oor die invloed van hierdie sienings op die invloedryke werke van die twintigste-eeuse gereformeerde teoloë Barth, Berkhouwer en Moltmann. 


\section{Introduction}

The concept human dignity has become a major directive in modern ethics. This concept underlies the modern constitutional state and has become an important guideline in the development of medical ethics, bio-ethics and the ethics of human rights. Since World War II Christian theology showed an increasing interest in human dignity as the leading principle in Christian anthropology, and in the way in which human dignity can be founded in Scripture and in the Christian tradition. It is a very popular theme in current philosophical, juridical and theological debates (Vorster, 2007:18).

Reformed theology with its strong emphasis on the social calling of Christians and the divine calling of the state is also deeply involved in these debates. Since the Reformation several theologians enunciated the implications of human dignity with reference to Calvin. Although reformed theology emphasises, like Calvin, the total depravity of humankind in its soteriology, it is fair to conclude that this theology does not depart from a total pessimistic view of humankind in its anthropology because of this angle of approach. Reformed theology also developed the implications of human dignity for human relations and holds the view that Scripture teaches the inherent human dignity of all people, which should be respected by fellow human beings and social institutions. Human depravity does not inhibit the inherent human dignity of persons in the eyes of fellow humans and social institutions (Witte, 2007:10).

Can the idea of human dignity be found in Calvin's anthropological teachings? Calvin indeed didn't use the term human dignity as the concept is interpreted today. Moreover, the concept as a constitutional principle was not known in his time. But, although the term human dignity in this sense does not feature in Calvin's social teachings, the idea is intertwined throughout his teachings about humankind and society, and especially in his view about the calling of the civil authority as a servant of God. The influence of Calvin's theology on modern democracy, in the sense of government by the people, has been discussed for a long time, although Calvin (Inst. 4.20.8.974), ${ }^{1}$ with the exception of one part in his Institutes, wrote no extensive treatise on politics and related matters (Leith, 1977:20; Witte, 2007:41). However, various references can be found

1 References to the Institutes of Calvin are done from the 2008 edition of the translation (Calvin, 2008). Where applicable, the translation was compared with the original text published by Baum (Calvin, 1864). 
regarding these issues in his huge corpus of writings, which was written over a period of 25 years (McNeil, 1965a:24).

This fact becomes evident when Calvin's heritage regarding the rights of people is examined. In a recent book Witte (2007) provides authoritative material about the influence of Calvin in the development of modern constitutionalism. He says the following in the introduction of this book:

Building in part on classical and Christian prototypes, Calvin developed arresting new teachings on authority and liberty, duties and rights, and church and state that have had an enduring influence on Protestant lands. Calvin's original teachings were periodically challenged by major crises in the West the French Wars of Religion, the Dutch Revolt, the English Revolution, American Colonization, and the American Revolution. In each such crisis moment, a major Calvinist figure emerged - Theodore Beza, Johannes Althusius, John Milton, John Winthrop, John Adams and others - who modernized Calvin's teachings and converted them into dramatic new legal and political reforms. This rendered early modern Calvinism one of the driving engines of Western constitutionalism. (Witte, 2007:xi.)

This article investigates Calvin's contribution to the current reformed perspective on human dignity and the way his ideas determined modern-day reformed ethics in this regard. The central theoretical argument of the article is that Calvin laid the foundation of the modern-day reformed reflection on human dignity as the concept can apply to human rights and bio-ethics. His vision becomes clear especially when his ideas of the image of God and common grace, natural law and civil authority are outlined. These issues will be dealt with in the article. In conclusion, the heritage of Calvin's views on these particular issues in post-war reformed ethical reflection will be described.

\section{The image of God and common grace}

Calvin's view on the creation of man in the image of God (imago dei) and the concept of common grace lies at the root of his view that humans have an inherent God-given dignity (Van Egmond, 1995: 1990). God created man in his image. The gift of God's image is present in every person. Due to this creational principle he stressed the worthiness of the human being. In his view the creation of humankind on the "sixth day" is especially important to note because God first created a dwelling place for people, then the angels to act 
as protectors of humankind. These actions were the prelude to the creation of humankind. Humankind was bestowed with a certain status. Humans are the noblest of the works of God and this fact is proof of God's justice, wisdom and goodness (Calvin, Inst. 1.15.1. 104). Humans are the mirror of his divine glory. The most distinguishing quality of humankind is its likeness to God, which seats in the intellect and in the abilities of the "soul" (Calvin, Inst. 1.15.4.179).

What happened to the created dignity of humankind after the fall? Here, the reader should differentiate between what in modern terms can be termed his soteriology and his anthropology. Due to the fall of Adam humankind lost its free will and any capability to rectify its destitute state. Seen from a soteriological angle of approach, humankind fell into total depravity. This depravity is a hereditary corruption to which early Christian writers gave the name of original sin "meaning by the term the depravation of a nature formerly good and pure" (Calvin, Inst. 2.1.5.150). Adam was not merely a progenitor, but a root and through his corruption the whole human race was deservedly vitiated. Original sin, then, may be defined according to Calvin as a hereditary corruption and depravity of our nature, extending to all parts of the soul, which first makes us obnoxious to the wrath of God and then produces the works which in Scripture are termed the "works of the flesh" (Calvin, Inst. 2.1.8.152). The only way to salvation is the free grace of God, expressed in the atoning sacrifice of Christ, which is applied by the Holy Spirit and received through faith and repentance by the helpless sinner (Calvin, Inst. 3.1.1.386).

However, in his anthropology Calvin based his teaching on morality, and the moral law on the dignity of the human person as a result of the imago dei. Although humankind's alienation from God due to the fall and its total depravity lead to the corruption of the imago dei, the creational dignity/nobility (nobilitas) of humans expressed by the imago dei has not been destroyed (Calvin, Inst. 1.15.4.107). ${ }^{2}$ When discussing humankind's depravity, Calvin (Inst. 2.1.3.148) adds: "It is not the will of God, however that we should forget the primeval dignity which he bestowed on our first parents - a dignity which may

2 "Quare etsi demus, non prorsus exinanitam ac deletam in eo fuisse Dei imaginem, sic tamen corrupta fuit, ut quidquit superest, horrenda sit deformitas." (CR:2-3:138.) 
well stimulate us to the pursuit of goodness and justice". 3 People maintain the dignity of their creation, and all the responsibilities flowing from this inherent dignity remain intact.

In his exposition of the extent of Christian love, Calvin (Inst. 3.7.6.12) also refers to the imago dei when he says:

In this way only we can attain to what is not to say difficult, but all together against nature, to love those that hate us, render good for evil, and blessing for cursing, remembering that we are not to reflect on the wickedness of men, but look to the image of God in them, an image which, covering and obliterating their faults, should by its beauty and dignity allure us to love and embrace them.

A violation of one's fellow man is a violation of God. The fall did not destroy the imago dei, and this characteristic of human existence became the foundation of the spiritual and civil liberties of the individual.

In conjunction with the concept of man created in the image of God lies the concept of the common grace of God upon all mankind. In addition to his providence and care God bestows upon man certain inherent gifts. Calvin (Inst. 2.2.15.167) says in this regard:

Therefore, in reading profane authors, the admirable light of truth displayed in them should remind us, that the human mind, however much fallen and perverted from its original integrity, is still adorned and invested with the gifts from its creator.

In this sense the whole human race can be regarded as one body reflecting the imago dei, with creational gifts under the common grace of God (Leith, 1989:184). As such humans have an inherent value and people should regard each other as people with value in the eyes of God.

The image of God and the gift of God's grace to humankind constitutes the foundation of Calvin's view of the responsibilities of individuals to each other, as well as the rights people have in interpersonal relations and over and against social institutions. It is the duty of all humans to see their fellow beings as creations of God with certain gifts and rights bestowed on them by Him. A true

3 "Neque tamen vult nos oblivisci Deus primae nobilitatis, quam Adae patri nostro contulerat, nempe quae nos ad iustitiae bonitatisque studium merito expergefacere debeat." (CR:2-3:178.) 
understanding of another comes only when one looks to God and sees God's reflection in that other person. God is seen reflected in all creation, even in unworthy sinners (Templin, 1988:165). It is therefore also the responsibility of the believer to act on behalf of others in order to promote justice (Wolterstorff, 1988:258). All people must be neighbourly. All people have a mutual responsibility, which entails mutual servitude (Templin, 1988:168). This responsibility and servitude must come to light in the protection of other people's rights.

In his thorough study of Calvin's viewpoint on the rights of individuals Witte (2007:57) compiled an interesting list of the rights Calvin had in mind, especially in his later writings. He indicates with authoritative references to Calvin's Institutes and his commentaries of various books in Scripture that Calvin speaks at times about the subjective "rights" (iuria, droits) of individuals, in addition to their "liberties" or "freedoms" (libertates, libertés). Sometimes, he used such general phrases as "the common rights of mankind" (iura commune hominum), the "natural rights" (iura naturali) of persons, the "rights of a common nature" (communes naturae iura), or "the equal rights and liberties" (pari iura et liberates) of all. Usually, he referenced more specific rights.

Furthermore, Witte (2007:58) explains that Calvin spoke, for example, about the "rights of Christian liberty", the "rights of citizenship" in the kingdom of God or in heavenly Jerusalem, and, one of his favourite expressions, the "right of adoption" that Christians enjoy as new sons and daughters of God and brothers and sisters in Christ. He referenced "the right to inhabit", "the right to dwell in", and "the right and privilege to claim the territory" that Yahweh gave to the chosen people of Israel. He mentioned "Paul's rights of Roman citizenship". He spoke frequently, as a student of Roman law would, about property rights: "the right to land, and other property", "the right to enjoy and use what one possesses", the "right to recover" and the "right to have restored" lost or stolen property; the "right to compensation" for work; the right "to sell", "to bequeath", and to "inherit" property, particularly in accordance with the "natural rights of primogeniture".

Witte (2007:58) further indicates that Calvin spoke of the "right to bury" one's parents or relatives. He also spoke frequently of the "marital" or "conjugal" rights of husband and wife, and the "sacred", "natural" and "common" rights of parents over their children - in particular, the "right" and "authority" of a father to "name his child", "to raise the child", and to set the child up in marriage. He spoke in 
passing about the "sacred right of hospitality" of the sojourner, the "right of asylum" or of "sanctuary" for those in flight, the "right of redemption" during the year of Jubilee, and the "natural rights" and "just rights of the poor, the needy, the orphans, and the widows".

All of these rights are founded in the dignity of human beings due to their creation in the image of God, which is the guiding principle of Christian love and in interpersonal relations. Another angle of approach to Calvin's view of the dignity of human beings is his view on the natural law.

\section{Natural law}

The concept natural law (ius naturalis or lex naturae) is, together with the above-mentioned principles, the foundation of Calvin's understanding of civil authority. In his distinction between the heavenly and the earthly kingdoms, Calvin refers to the moral law that God uses to govern both the kingdoms. This moral law is engraved in the conscience, repeated in the Scripture and summarised in the Decalogue (Witte, 2007:59). It is a gift of creation to all people and that is the reason why unbelievers can also act morally in order to maintain order and discipline in society. Witte (2007:59) explains that Calvin uses a variety of terms to describe this moral law such as: "the voice of nature", "the engraven law", "the law of nature", "the natural law", "the inner mind", "the rule of equity", "the natural sense", "the sense of divine judgement", "the testimony of the heart", "the inner voice" and others. In this respect he agreed with his predecessors in the Reformation (McNeil, 1965a:168) who used the concept lex naturae (natural law).

According to Calvin (Inst. 2.7.1.219) the natural law of God is more than the Ten Commandments given to his chosen people. In his introduction to his discussion of the Ten Commandments Calvin speaks about the law given to all people. This law is "the very things contained in the two tables ... dictated to us by that internal law, which as already been said, is in a manner written and stamped on every heart". In the same discussion he refers to this law as the natural law. In his commentary on Romans. 2:14-15 he states clearly that a certain conception of justice is engraved in the minds of all men (Calvin, 1964:48). The same idea is developed in his sermons on Deuteronomy 4:44-6:4 and 19:14-15.

These terms, as Calvin used them, were well researched and explained by Bohatec (1934:3 and 1962:19) as follows: "Die lex naturae ist vornehmlich der Inbegriff der praktischen, dem Menschen- 
geist angeborenen rechtlichen und sittlichen Prinzipien (iustitiae ac rectitudinis conceptiones) die die Griechen als proletheis bezeichnet haben." 4 Every person has a sense of justice and civil authority has the obligation to develop this sense of justice. This sense of justice is an indication of the dignity of people and their ability to maintain good order in society, but also of their responsibility to keep these God-given laws in high regard.

In governing humanity God has three uses for the natural law. Firstly, God uses the law theologically. In this respect the law is used to condemn all persons in their conscience and to compel them to seek the liberating grace. Secondly, He uses the natural law civilly in order to restrain the sinfulness of non-believers who have not accepted his grace. In the third place, He uses the natural law educationally to teach believers the means and measures of sanctification and spiritual development (Witte, 2007:59-60).

However, the natural law is openly written in the Ten Commandments for the clearer understanding of the believers. On the basis of the Ten Commandments the magistrate is the custodian of both tables of the Decalogue.

The duty of the magistrates, its nature as described by the word of God, and the things it consists, I will here indicate in passing. That it extends to both tables of the law, did Scripture not teach, we might learn from profane writers; for no man has discoursed of the duty of magistrates, the enacting of laws, and the common weal, without beginning with religion and divine worship. (Calvin, Inst. 4.20.9.975.)

The rulers have specific responsibilities to administer justice among men, and in this regard he refers to Jeremiah 22:3 and Psalms $82: 3,4$. Natural law as it is precisely summarised in the Ten Commandments determines the responsibility of the civil authority in protecting the dignity of people.

Calvin's concept of the natural law was very influential in the postreformation development of jurisprudence and the emerging reformed view on the authority and task of the civil authorities. His idea was introduced by Johannes Althusius of the Dutch Republic in the development of Roman-Dutch Law. Just as Calvin, Althusius maintained that God has written his natural law on the hearts, souls,

4 This principle has also been developed in the subsequent reformed jurisprudence (cf. Van der Vyver, 1975:17). 
minds, and consciences of all persons. This natural law teaches persons higher ideas that appeal uniquely to human reason and conscience. Through the natural law, God commands all persons to live a life that is at once pious and holy, just and proper. Witte (2007:157) quotes Althusius and indicates that he said that God teaches people the "natural duties of love that are to be performed toward God and one's neighbour". Furthermore, Althusius said:

God teaches and writes on human hearts the general principles of goodness, equity, evil and sin, and He instructs, induces and incites all persons to do good and avoid evil. He likewise condemns the conscience of those who ignores these things and excuses those who do them. He thereby directs them to goodness and dissuades them from evil. If they follow the path of goodness, he excuses them. If they do not He condemns them. (Witte, 2007:158.)

The idea of the lex naturae as it features in the teachings of Calvin and his followers, especially Beza and Althusius, is a further indication that Calvin nurtured the idea of the basic dignitas of people in his anthropology and his social teachings. Any modern ideology that rejects the idea of the basic dignity of all people with reference to the soteriology of Calvin and the Reformation, does not understand this important guiding principle in reformed anthropology. Besides his teachings on the effect of the imago dei and common grace and his point of view regarding the lex naturae, Calvin applied the principle of the dignitas of people in his ideas about the responsibility of the civil authority.

\section{Civil authority}

On the basis of the above-mentioned principles, Calvin formulated his views on the responsibilities of the civil government, not only to maintain the good order and to honour God, but to protect the dignity of people. The government is exhorted in this age "to foster and maintain the external worship of God, to defend sound doctrine and the condition of the Church, to adapt our conduct to human society, to form our manners to civil justice, to conciliate us to each others, to cherish common peace and tranquillity" (Calvin, Inst. 4.20.2.259). 5 In the execution of this task the civil authority should

$5 \quad$ McNeil (1948:155) reveals another angle of approach in the social thinking of Calvin. He argues that Calvin defined his political ideas about the task of the civil government on the basis of his views of the perfections (vistudes) of God according to Jeremiah 9:24. These are misericordia (mercy), iudicium (judge- 
first of all be obedient to God, because they represent God's tribunal on earth (Calvin, Inst. 2.8.46.352) but are also accountable to the people in their exercise of power (Calvin, 1867:310; 1864:367). "For they rule not for their own cause, but for the common profit; neither are they endued with an infinite or unlimited power, but such as is tied to the health of their subjects (sed quae subditorum saluti sit obstricta)." (Calvin, 1864:367.)6

It is the task of the civil authority to maintain law and order because the sin of human nature creates the need for civil order. In his commentary on Jeremiah 30:9, Calvin (1854b:15) says:

It would, indeed, be better for us to be wild beasts and to wander in forests, than to live without government and laws; for we know how furious are the passions of man. In the maintenance of morality the king should be an example to the people, because ... it is especially notorious, that the anger of God is provoked against the whole body of people, in the person of the king. (Calvin, 1867:528.)

The government should not exploit the people and must not entice them to worship idols (Calvin, 1852:210). This is another example of Calvin's emphasis on the fact that the government is responsible to God and accountable to its subjects. The latter aspect has to date largely been neglected in research on Calvin's view of the civil authority. Calvin did not enter into an extended explanation on the kind of government which will be the ideal for a Christian. He took a very strong stand against any form of tyranny because he regarded it as a violation of human dignity. His view is clearly evident in his discussion of the conduct of the Farao as it is described in Exodus 5:9 (Calvin, 1984:97). 7 He criticised the monarchy, because monarchy is prone to tyranny. On the other hand, aristocracy can lead to the tyrannical rule of a few and a popular government can lead to anarchy. His well-known option is for an "aristocracy, either pure or modified by popular government" (Calvin, Inst. 4.20.8.974). Here also, he is adamant that the freedom of people should not be

ment) and iustitia (righteousness). In the execution of righteousness the civil government should take care of the poor and the needy and protect the dignity of people.

$6 \quad$ See in this regard also the viewpoint of Strauss (1998:28).

7 A thorough discussion of Calvin's view is presented by Bouwsma (1988:208). 
betrayed (Calvin, Inst. 4.20.31.988). 8 The dignity of the people should always be respected.

Church and state are separate entities. The state should, however, defend the true worship and take care of the well-being of the church as long as this intervention does not lead to disturbance of the order and discipline in the church (Calvin, Inst. 4.11.16.810). Both church and state are subjected to the authority of God, as this authority is expressed in God's written Word (cf. Leith, 1989:199). 9 Calvin does not devalue the civil authority to the sphere of the secular as was done by Augustine in his influential City of God. Augustine (1960:65) was of the opinion that the earthly city seeks an earthly peace and entails the merging of human wills with regard to the things that are useful for this mortal life. Calvin's views also differed from those held by Luther. Luther (1962:473) disengaged church and state completely. In the Calvinist tradition of the early twentieth century Calvin's views were also altered to accommodate modern politics. 10 This was particularly the case in the neo-Calvinism of the twentieth century. This fact is important to note because of the modern-day tendency to read Calvin from a modern political perspective.

8 Calvin says in the Latin edition:

Adeo illos ferocienti regum licentiae pro officio intercedere non veto, ut si regibus impotenter grassantibus et humili plebeculae insultantibus conniveant, eorum dissimilationem nefaria perfidia non carere affirmem: quia populi libertatem, cuius se Dei ordinatione tutores positos norunt, fraudulenter produnt. (CR:2-3:1115.)

So far am I from forbidding these officially to check the undue license of kings, that if they connive at kings when they tyrannise and insult over the humbler of the people, I affirm that their dissimulation is not far from nefarious perfidy, because they fraudulently betray the liberty of the people, while knowing that, by the ordinances of God, they are its appointed guardians.

$9 \quad$ Regarding this issue Witte (1996:398) remarks:

Within this unitary society, the church and the state stand as coordinate powers. Both are ordained by God to help achieve order and discipline in the community, a successful realisation of all three uses of the moral law. Such conjoined responsibilities inevitably required church and state, clergy and magistracy to aid and accommodate each other on a variety of levels.

10 In this respect the Christocentric foundation of civil government of Barth (1960:102) and the institutional view of the neo-Calvinism of the Dutch theologian Kuyper (1943:82) can be mentioned. 
It is also important to stress the fact that Calvin did not regard the state as neutral. The modern-day concept of a neutral or secular state cannot be found in Calvin's ethics and the claims of modern reformed theology in this respect are not valid. For him each community "is a unitary Christian society, a corpus christianum under God's sovereignty and law" (Witte, 1996:398). Still the civil authority had to respect and protect the dignity of all people, irrespective of religion or creed. Within the context of the abovementioned explanation of Calvin's view of the authority of the civil government, the conclusion can be reached that Calvin had a high regard for the innate dignity of human beings and that this fact, inter alia, determined his view on the responsibilities and obligations of civil authorities.

\section{Calvin's heritage in the modern reformed tradition}

In his expansive book Witte (2007:81 ff.) indicated that Calvin's view was highly influential in the three centuries following the Reformation. This article will not repeat his findings, but will focus shortly on this heritage as it featured in the post-World War II reformed ethical reflection. 11 This debate can now move on to the question: Does Calvin's ideas on the dignity of people have any bearing on the modern-day concept of human dignity and human rights? Could modern theologians find any foundation in Calvin's theology for their contribution to the development of a modern reformed ethics of human dignity and human rights? Ritschl $(1980: 333,345)$ answers this question positively, but says that human rights and Calvinism may seem a contradictio in terminis, because in the modern democracies concepts of human rights and liberty of conscience are important, while it seems that Calvin emphasised order and punishment for heresy. He also warns against the temptation to read the modern-day concept of human rights into Calvin. In spite of this

11 Other earlier authors reached the same conclusions. McNeil (1965:20) argues that the political ideas of Calvin influenced the jurist Grotius, who is widely regarded as the founder of modern international law. He also states that influential leaders who adhered to the Calvinist view of political order promoted the concept of democracy, for example, Bocsky (d.1606) and Bethlen (d.1629) in Hungary, Cromwell (d.1656) in England, John de Witt (d.1672) in the Dutch Republic, William Penn in New England and Rabant (d.1793) and Guizot (d.1874) in France. According to him they all promoted the concept of democracy in the sense that the leader is accountable to the people and may be deposed by the people. Leith (1989:206) is of the opinion that Calvinism as it took shape in English Puritanism contributed to political democracies that developed in England and later to the colonies. 
proviso he concludes that Calvinism contributed constructively to the modern-day concept of human rights.

Another historical fact should also be taken into account in the study of Calvin's heritage regarding the modern-day concept of human dignity and human rights. What Schild says about Luther is also applicable to Calvin. He (Schild, 1989:11) says:

Luther was a child of his time. And while humanism, in contact with earlier sources, was herald of a wider, more generalising and optimistic concept of humanity, rights in Luther's day mostly remained special to, or determined by, the medieval estates, orders and social classes into which people were born and moved.

However, modern research indicates that the root of an ethics of human dignity and human rights can be found in Calvin's theology. Reformed theologians after the Reformation furthered his argument of the dignity of humankind - especially in the twentieth century with the emergence of the idea of human rights against the background of the human rights abuses in World War II. The contributions of three prominent reformed theologians can be mentioned in this respect, namely Barth, Berkhouwer and Moltmann.

Barth (1961:116) emphasised the relational aspect of the imago dei. The imago dei is an expression of God's willingness to enter into a relation with humankind. Man has become a relational being and in his expression of relations of love and care, a person expresses his basic dignity. In other words, people's ability to express humaneness is a sign of the imago dei (cf. Westermann, 1973:344). For what reason does God forbid manslaughter and why is the preservation of life so important in the Old Testament laws? (Barth, 1961: 344) The purpose of human conduct is to preserve and protect life and everything it entails, such as humaneness, compassion, caring and social concern. On this basis Barth designed a Christian anthropology that revived Calvin's ideas and resisted the individualism and rationalism of the Aufklärung (Price, 2002:97).

At the same time the prominent Dutch theologian Berkhouwer (1957:34) reflected on the relevance of the imago dei for modern ethics and social concern. He also maintains that the doctrine of imago dei is essential for the development of a relevant Christian anthropology. Through the imago dei and the atonement in Christ, a human being becomes man of God, and receives as such the ability to strive after the justice of the kingdom of God. However, the main ethical implication of the imago dei is that it sets the possibility for 
humans to be free from any form of slavery and lack of freedom due to the blemishes of sin and feelings of guilt. Therefore, any person who uses the imago dei as an angle of approach should support a nations' call to freedom, and the Christian church should also support their desire for freedom (Berkhouwer, 1957:369). The consequence of Berkhouwer's view within the framework of the topic under discussion is that the imago dei sets the stage for people to seek liberation by way of repentance and forgiveness. This doctrine says that in a world of suffering and hardship, people can achieve peace by respecting human dignity, seeking the kingdom of God and embodying forgiveness. Just as Barth, Berkhouwer applied Calvin's ideas about the social relevance of the imago dei to a relevant Christian ethic.

The same is true of the influential public theology of Moltmann. Moltmann (1997:1) developed the ethical implications of the imago dei even further. He also maintains that the concept is a theological concept with clear ethical implications. The concept should be explained in its close relationship with the imago Christi and Gloria Dei est homo (Moltmann, 1993:216). It says something about God, who created an image and then entered into a close relationship with that image. Therefore the imago dei is all about relationships - the relation between God and humankind and interrelations between humans. Humans are thus created as relational beings. They relate to God, to each other and to the rest of creation. They are representatives of God in this world to care for his work as stewards. The imago dei should be manifested not only in a few human characteristics, as early reformed theology argued, but in the totality of human existence. He says: "The whole person, not merely his soul; the true human community, not only the individual; humanity as it is bound up with nature - it is these which are the image of God and his glory." (Moltmann, 1993:221.) The imago dei explains what human beings are and not what they have (cf. also Wright, 2004:119; Vorster, 2007:75).

\section{Conclusion}

The biblical idea of imago dei, as it was argued by Calvin and is currently applied in the reformed tradition, has concrete implications for Christian anthropology and social ethics. Not only does this concept explain the core value of human dignity, but it is essential to any approach to humaneness and human relationships.

God invested humankind with human dignity, not a dignity equivalent with God, but before God. The richness of this dignity lies in the 
relationships of humankind - the relation with God, with each other and with creation. Human dignity also enables humans to fulfil their calling to be stewards of creation. Preuss (1991:238) says:

From the beginning, God has given the world to humanity. The world, and that does simply mean fellow human beings, is the object of human moral behaviour and discourse (cf. Ps. 8) and humanity may and should order the world responsibly before this God and in relationship with him.

Although Calvin did not use the term human dignity or human rights as they are understood in modern constitutialism, he laid the foundations for the development of such a reformed ethics of human dignity and human rights with his emphasis on the dignitas of human beings due to the imago dei. He paved the way for an anthropology that appreciates core moral directives such as compassion, humaneness, life and love and which serves as a corrective to all forms of anthropologies founded in racism, xenophobia, tribalism and sexism. In spite of the modern inclination to accuse Calvin of a pessimistic view of humankind due to his emphasis on total depravity in his soteriology, he laid the foundation of the modern "human face" and immense potential to the social relevance of reformed ethics today. This can be seen as a reason for the renewed interest in the ideas reformed ethics can offer regarding the human rights debate and to the development of bio-ethics.

\section{List of references}

AUGUSTINE, A, 1960. De civitate Dei contra paganos. London: Heineman. BARTH, K. 1960. Community, state and church. New York: Double Day.

BARTH, K. 1961. Church dogmatics: the doctrine of creation. Vol. 3, part 4. Trans. by A.T. Mackay et al. Edinburgh: Clark.

BERKHOUWER, G.C. 1957. Dogmatische studiën: de mens het beeld Gods. Kampen: Kok.

BOHATEC, J. 1934. Calvin und das Recht. Vienna: Bohlhaus.

BOHATEC, J. 1962. Calvins lehre von Staat und Kirche, mit besonderer Berucksichtigung des Organismus gedankens. Breslau: Scientia Aalen.

BOUWSMA, W.J. 1988. John Calvin: a sixteenth-century portrait. Oxford: Oxford University Press.

CALVIN, J. 1852. Commentaries on the book of the prophet Daniel. Edinburgh: Calvin Translation Society.

CALVIN, J. 1854a. Commentaries on the book of the prophet Jeremiah and the Lamentations. Edinburgh: Calvin Translation Society.

CALVIN, J. 1854b. Commentaries on the first book of Moses called Genesis. Edinburgh: Calvin Translation Society.

CALVIN, J. 1864. Institutio Christianae Religionis. (In Baum, G. et. al., eds. Corpus Reformatorum. Vols. 2-3. Brunsvigae: Schwetscke.) 
CALVIN, J. 1867. Commentaries on the twelve minor prophets. Edinburgh: Calvin Translation Society.

CALVIN, J. 1964. Commentary upon the epistle of Saint Paul to the Romans. Edinburgh: Calvin Translation Society.

CALVIN, J. 1984. Harmonie van de laatste vier boeken van Moses. Eerste deel. Kampen: Goudriaan.

CALVIN, J, 2008. Institutes of the Christian religion. Peabody: Hendrikson.

KUYPER, A. 1943. Calvinism: six stone foundation lectures. Grand Rapids: Eerdmans.

LEITH, J.H. 1977. An introduction to reformed tradition: a way of being the Christian community. Atlanta: John Knox.

LEITH, J.H. 1989. John Calvin's doctrine of the Christian life. Louisville: Westminster.

LUTHER, M. 1962. Lectures on Romans. St. Louis: Concordia.

MCNEIL, J.T. 1965a. John Calvin and civil government. (In Hunt, G.L. Calvinism and the political order. Philadelphia: Westminster. p. 21-39.)

MCNEIL, J.T. 1965b. Calvinism and European politics. (In Hunt, G.L., ed. Calvinism and the political order. Philadelphia: Westminster. p. 1-20.)

MOLTMANN, J. 1993. God in creation. Minneapolis: Fortress.

MOLTMANN, J. 1997. The original study paper: the theological basis of human rights and of the liberation of human beings. (In Miller, A.O. A Christian declaration of human rights. Major Rapids: Eerdmans. p. 25-34.)

PREUSS, H.D. 1991. Old Testament theology. Vol. 1. Louisville: Westminster John Knox.

PRICE, D.J. 2002. Karl Barth's anthropology in light of modern thought. Major Rapids: Eerdmans.

RITSCHL, D. 1980. Der Beitrag des Calvinismus für die Entwicklung des Menschenrechtgedankens in Europa und Nord Amerika. Evangelische Theologie, 40(4):333-345.

SCHILD, M.E. 1989. Being a Christ to the neighbour: Luther and the development of human rights. Lutheran theological journal, 23(1):11.

STRAUSS, P.J. 1998. God's servant working for your own good: notes from modern South Africa on Calvin's commentary on Romans 13:1-7 and the state. Hervormde teologiese studies, 54(1):28.

TEMPLIN, J.A. 1988. The individual and society in the thought of Calvin. Calvin theological journal, 23(2):161-177.

VAN DER VYVER, J.D. 1975. Die beskerming van menseregte in Suid-Afrika. Kaapstad: Juta.

VAN EGMOND, A. 1995. Calvinist thought and human rights. (In Addullali, A-A., ed. Human rights and religious values: an uneasy relationship? Grand Rapids: Eerdmans. p. 190-205.)

VORSTER, N. 2007. Restoring human dignity in South-Africa. Potchefstroom: Potchefstroom Theological Publications.

WESTERMANN, C. 1973. Forschung am Alten Testaments: gesammelte Studien. Band 2. München: Christliche Kaiser Verlag.

WITTE, J, 1996. Moderate religious liberty in the theology of John Calvin. Calvin theological journal, 31(1):359-403.

WITTE, J. 2007. The reformation of rights: law, religion, and human rights in early modern Calvinism. Cambridge: Cambridge University Press.

WOLTERSTORFF. N, 1988. Can a Christian be progressive? Gereformeerd theologisch tijdschrift, 88(1):249-258. 
WRIGHT, C.J.H. 2004. Old Testament ethics for the people of God. Leicester: InterVarsity.

\section{Key concepts:}

Calvin

Calvinism

human dignity

imago dei

lex nature

Kernbegrippe:

Calvinisme

Calvyn

imago dei

lex nature

menswaardigheid 
